\title{
AUTOMATED GUIDED VEHICLES (AGV): SEARCHING A PATH IN THE FLEXIBLE MANUFACTURING SYSTEMS
}

\section{POJAZDY KIEROWANE AUTOMATYCZNIE (AGV): POSZUKIWANIE DROGI W ELASTYCZNYCH SYSTEMACH WYTWARZANIA}

\author{
Omar Lengerke ${ }^{1,3}$, Max S. Dutra ${ }^{1}$, Felipe M.G. França ${ }^{2}$, \\ Magda J.M. Tavera
}

(1) Mechatronic Systems \& Robotics Research Group - COPPE/UFRJ

Federal University of Rio de Janeiro - CEP 21.945-970 - Rio de Janeiro, RJ, Brazil

www.labrob.coppe.ufrj.br

(2) System Engineering and Computer Science Program - COPPE/UFRJ

Federal University of Rio de Janeiro, Postal Box 68.511 - Rio de Janeiro, RJ, Brazil

(3) Mechatronics Engineering Program, UNAB,

Autonomous University of Bucaramanga - Bucaramanga, Colombia,

E-mails: (1)max@mecanica.coppe.ufrj.br (2) felipe@cos.ufrj.br

(3) olengerke@unab.edu.co

\begin{abstract}
Manufacturing systems are undergoing a noticeable evolution due to an intense technological progress in industrial robotics. Serial production has evolved into the concept of Flexible Manufacturing Systems (FMS), which encapsulate processes in automatic equipment that are capable of executing different operations, that before be performed in several stages and diverse equipments. Automated Guided Vehicle (AGV) systems have been frequently used as material handling equipment in manufacturing systems since the last two decades. Particularly, AGV's with trailers are, and will continue to be, the backbone of the material transport industry. The use of these systems has taken the attention of experts and researchers. They are numerous studies concerning AGV with trailers systems in literature; few of them deal with the adaptation of these systems into FMS. In this paper, a study of the trajectories and a simulation model of a hypothetical system, which included a FMS environment, were developed. In addition, a potential field's method was explored in order to improve the ability of detecting obstacles in AGV's with trailers moving through stations.
\end{abstract}

Keywords: Flexible Manufacturing Systems, Automated Guided Vehicle, Trajectories Planning.

Streszczenie: Produkcja seryjna wyewoluowała w kierunku koncepcji Elastycznych Systemów Wytwarzania (FMS), która obejmuje procesy technologiczne wykonywane przy zastosowaniu urządzeń automatyki. Od dwóch dekad do transportu i podawania materiałów w systemach wytwarzania stosuje się często układy Pojazdów Kierowanych Automatycznie (AGV). W szczególności, takie pojazdy $\mathrm{z}$ przyczepami są i $\mathrm{w}$ dalszym ciągu będą szkieletem systemów do transportu materiałów produkcyjnych. W niniejszym artykule przedstawiono badania nad trajektoriami (trasami przejazdów) i modelem symulacyjnym takiego hipotetycznego systemu, który został opracowany jako część środowiska Elastycznych Systemów Wytwarzania (FMS). Dodatkowo została zbadana potencjalna metoda badań w terenie pozwalająca na poprawę wykrywalności przeszkód utrudniających ruch Pojazdom Kierowanym Automatycznie z przyczepami przejeżdżającymi przez stacje.

Słowa kluczowe: Elastyczne Systemy Wytwarzania (FMS), Pojazdy Kierowane Automatycznie (AGV), planowanie trajektorii (tras przejazdów) 


\section{Introduction}

The evolution of robotics is influenced by the new demands of customers on the characteristics of products of service (quality, quantity and time). One of these evolutions or developments are the manipulators used by Flexible Manufacturing Systems (FMS), which have obvious advantages on acting in repetitive tasks (assembly, painting, etc.). However, such structures have limited movements within it's surrounding, differently from mobile robots, that can accomplish movements along a factory, deviating obstacles, producing flexibility; a tireless search of the industries. With the development of navigation technologies for autonomous vehicles and the increase of the processing capacity of the new computers, application possibilities are enlarged. On the international plane, the application field of mobile robots is not restricted to the industry; it is significantly wider, also reaching the areas of logistics (distribution and storage), oceanographic and underwater exploration, planetary exploration, and military applications. Currently in the industry, and specifically in existing industrial projects of mobile robotics, the main target applications are in manufacturing (factories, cells and flexible manufacturing systems) and in the logistics of supply chain and storage and services. In the last years, there has been a lot of interest in the development of applied technologies in AGV's, from the automation of tasks involving transfer and loading of materials to simple inspection tasks. This involves controlling the movement of the vehicles, from an initial point to an end point, offering great improvement in the reduction of risks, time of transfer and energy consumption. In the manufacturing industry, common types of vehicles are AGV's with trailers (Tow/Tugger) that are developed for the transport, load and unload of materials between different stations to work within the FMS. AGV systems are considered as one of the most appropriate modes for material handling support of contemporary flexibly automated production environments. In general, such a system consists of a set of cooperating driverless vehicles which transport goods and materials among the different workstations and storage sites of a production facility. Usually, AGV's follow a set of predetermined, physical or virtual guidepaths embedded into the facility layout, and are coordinated by a centralized or distributed computerbased control system. Some of the primary advantages attributed to these environments are increased routing flexibility, space utilization and safety, resulting in a reduced overall operational cost (Reveliotis, 2000). The research on the design and operation of AGV systems with trailers, especially, involve highly interdisciplinary technological areas such as electronics, mechanics, control and computing that, synergeticaly integrated on projects and products or manufacturing processes, created the concept of "Mechatronics" (Lengerke and Dutra, 2007). 
Automated Guided Vehicles (AGV): Searching a Path in the Flexible....

Pojazdy kierowane automatycznie $(A G V)$ : poszukiwanie drogi...

\section{Navigation and Planning of AGV's on Flexible Manufacturing Systems}

FMS is designed to manufacture a variety of items or products simultaneously and to provide alternative processing routes for individual products. The flexibility dimensions can be characterized in no routing flexibility, flexible alternative machines, flexible alternative operation sequences and full routing flexibility. The planning component of paths on FMS consists of a mission planner, navigator and pilot. Guidepath design is an important problem in AGV system design and is one of the very first problems to be considered. The guidepath depends greatly on the allocation of shop-floor space, layout of storage zones and the arrangement of handling stations (Le-Anh and De Koster, 2006). In most cases, the shop-floor space is fixed and it imposes constraints on the guide-path design problem. The vehicle guide-path is usually represented such that aisle intersections, pick-up and delivery locations can be considered as nodes on a graph connected by a set of arcs. Arcs describe the paths that vehicles can follow when moving from node to node. Directed arcs between two nodes indicate the direction of the vehicle flow. Cost can be assigned to each arc representing the distance between the two end points of a segment or the time required by a vehicle to travel along the arc.

\subsection{Potential Field Methods}

During the past few years, potential field methods (PFM) for obstacle avoidance have gained increased popularity among researchers in the field of robots and mobile robots. One of the reasons for the popularity of this method is its simplicity and elegance. In this work, maps of cells already constructed and potential fields are used, for the purpose of planning for local paths. One of the goals is to study a navigation system for an $\mathrm{AGV}$ that allows using potential fields, to navigate along a collision-free path form an initial point to an end point, consequently, it is made a description of this method and presented the proposals of some authors. The PFM was brought to the computer world in 1978 by Khatib and Lemaitre and reused for the same authors, in other work later (Khatib, 1985). Used as a local method (Latombe, 1991) and having been, later, widely used in global strategies and dominantly approached for planning and control of mobile robots (Lengerke, et al., 2007). The underlying idea of the method is to fill the AGV's workspace with a virtual potential field in which the vehicle is attracted to its goal and is repulsed away from the obstacles (Figure 1). 


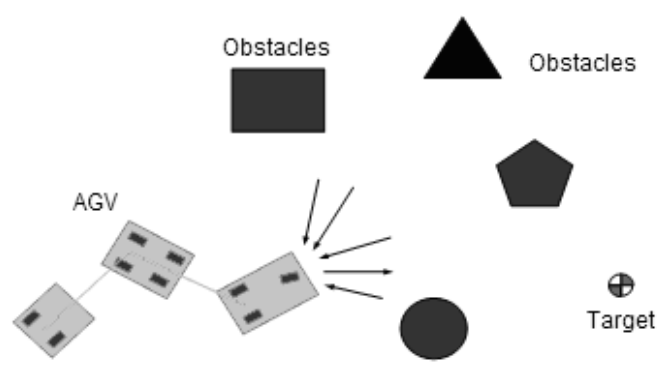

Fig. 1 Influence of potential field on AGV with trailers.

The intensity of the field does not depend on the velocity of the particles, as the field is radial; it is enough to know the distances among particles to get to define the potential function completely. In this method, is considered $x$ as a position of a point that moves in a forces field. The target provides an attractive force and obstacles, repulsive forces. Although this method has been initially introduced to manipulators, its application to mobile robots is also possible. The PFM is named to the fact that the field (vector) of forces $F(x)$ is derived form the field (scalar) potential $U(x)$, with:

$$
F(x)=-\nabla[U(x)]
$$

The AGV control is obtained subjecting it to the virtual potential field determined by:

$$
U(\vec{x})=U_{a t r}(\vec{x})+U_{r e p}(\vec{x})
$$

Where $U(\vec{x})$ is the resultant potential, $U_{\text {atr }}$ is the attractive potential (Figure 2) generated by target point $\left(x_{o b j}\right), U_{\text {rep }}$ is the repulsive potential (Figure 2) generated by the obstacles and $\vec{x}=(x, y)^{T}$ is the position vector of AGV. Actuate virtual force $F(x)$ in the $\mathrm{AGV}$ is defined by the command vector of the equation (3).

$$
\vec{F}(\vec{x})=\vec{F}_{\text {atr }}(\vec{x})+\vec{F}_{\text {rep }}(\vec{x})
$$

Where $F_{a t r}$ is an attractive force that guides the control point of the robot to the target, and $F_{r e p}$ is a force which induces a virtual repulsion the surface of the obstacle produced by $U_{\text {rep }}(x)$. 


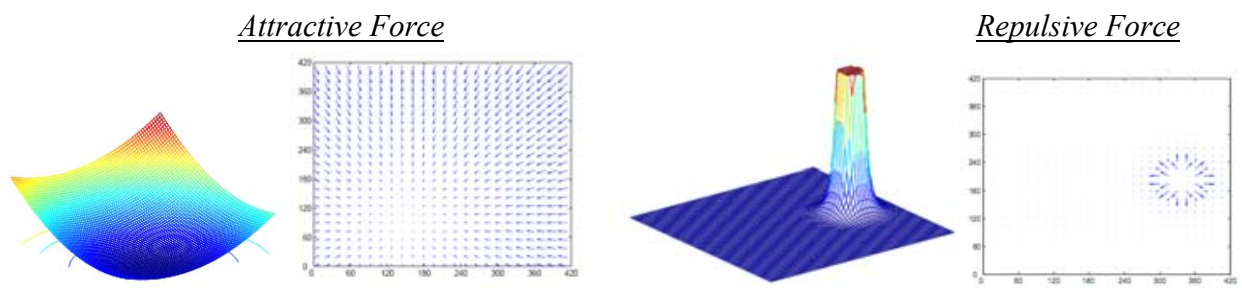

Fig. 2 Attractive potential field generated by a target point and their induced forces (left) and repulsive potential field generated by an obstacle and their induced forces (right) [4].

The calculation proposed by Khatib (1985) of the attractive component is performed using a quadratic relationship (parabolic function) not negative, whose first derived is continues and it possesses a single null value in $\vec{x}=\vec{x}_{o b j}$ and that depends on the positions of $\operatorname{AGV}(\vec{x})$ center, and of the target $\left(\vec{x}_{o b j}\right)$ defined for:

$$
U_{a t r}(\vec{x})=\xi\left(\vec{x}-x_{o b j}\right)^{2} / 2
$$

Where $\xi$ is a factor of positive scale of attractive potential field. The induced force by attractive potential field is certain from the equation (3) and results in:

$$
\vec{F}_{a t r}(\vec{x})=-\vec{\nabla} U_{a t r}(\vec{x})=-\xi \rho_{o b j}(\vec{x}) \vec{\nabla} \rho_{o b j}(\vec{x})=-\xi\left(\vec{x}-\vec{x}_{o b j}\right)
$$

The artificial potential field defined conduces to a stable system. However, to assure the asymptotic stability of the system a dissipative force proportional to the velocity $x$ is added. Thus $k_{d i s}$ a gain of velocity, the forces that contribute to the movement and $\mathrm{AGV}^{\prime}$ 's stability is of the form:

$$
F_{a t r}^{*}(x)=-\xi \rho_{o b j}-k_{d i s} \dot{x}
$$

Where $\dot{x}=(\dot{x}, \dot{y})^{T}$ with $\dot{x}=v \cos (\phi)$ and $\dot{y}=v \operatorname{sen}(\phi)$, is $v$ a magnitude of linear velocity and $\phi$ the navigation direction of the AGV for a reference external. The calculation of the repulsive potential field generated by the obstacles, using a less distance to the obstacles $\rho(\vec{x})$ is given by equation (7), Where $\rho_{0}$ a positive constant that represents a distance limit of influenced of the repulsive potential 
field, $\eta$ is the positive scale factor and $\rho(\vec{x})$ represent a less distance of indicated point for $\vec{q}$ and obstacles for $\rho(\vec{x})=\min \|\vec{x}-\vec{x}\|$ with $\vec{x}$ a pertinent point to the obstacles.

$$
U_{\text {rep }}(\vec{x})=\left\{\begin{array}{c}
\frac{1}{2} \eta\left(\frac{1}{\rho(\vec{x})}-\frac{1}{\rho_{0}}\right)^{2}, \text { se } \rho(\vec{x}) \leq \rho_{0} \\
0, \text { se } \rho(\vec{x})>\rho_{0}
\end{array}\right.
$$

The choice $\rho_{0}$ depends on the maximum velocity and capacity of deceleration of $\mathrm{AGV}$. The induced force by the repulsive potential field given by equation (7) is obtained considering the symmetric of the gradient of the repulsive potential field, thus applying the gradient:

$$
\begin{aligned}
& F_{\text {rep }}(\vec{x})=-\vec{\nabla} U_{\text {rep }}(\vec{x}) \\
& F_{\text {rep }}(\vec{x})=\left\{\begin{aligned}
\eta\left(\frac{1}{\rho(\vec{x})}-\frac{1}{\rho_{0}}\right) \frac{1}{\rho^{2}(\vec{x})} \vec{\nabla} \rho(\vec{x}), \text { se } \rho(\vec{x}) \leq \rho_{0} \\
0, \text { se } \rho(\vec{x})>\rho_{0}
\end{aligned}\right.
\end{aligned}
$$

Where $\vec{\nabla} \rho(\vec{x})$ is the unit vector of the partial derivative of the distance between the AGV center and the obstacle, determining the direction that the force is applied. Considered the existence of $n$ obstacles, the total repulsive force is given by the sum vector of repulsive forces $\vec{F}_{r e p, k}^{*}(\vec{x})$, exerted by each of the obstacles and resultant force (Figure 3), given by:

$$
\vec{F}_{r e p}^{*}(\vec{x})=\sum_{k=1}^{n} \vec{F}_{r e p, k}(\vec{x}) ; \quad F^{*}(x)=F_{a t r}^{*}(x)+F_{r e p}^{*}(x)
$$
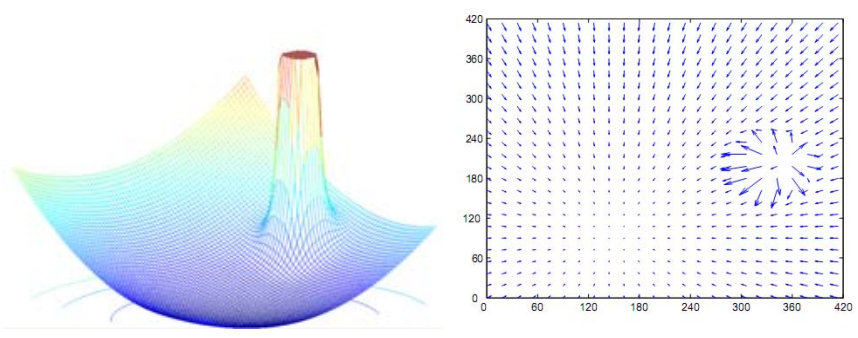

Fig. 3 Resultant potential field and induced forces by field. 
The method of the potential field can be used for off-line global planning, when the environment of AGV is known a priori, as is the case of FMS, or in on-line local planning when the environment is unknown and the presence of obstacles will be detected by sensors of AGV. Under the influence of the virtual potential field, the AGV moves in the symmetrical direction of the gradient, of areas of highest potential for areas of lowest potential, where the gradient is null. However, the virtual potential field is a local method that does not attend to the restrictions nonholonomics of $\mathrm{AGV}$ and presents problems for possessing other minimal (local) where the gradient is null. Thus, AGV can be blocked in a local minimal. Solutions to this problem are proposed as the definition of potential to take one of a few local minimal (global method), to include techniques to escape the local minimal, apply random forces, cooperation or use the navigation functions (potential functions without local minimal). A solution was made by Chengqing, et al., (2000), in a very interesting work that creates the concept of virtual obstacle to eliminate the greatest failure of the various potential functions tried already; the local minimal.

\subsection{Kinematics Model of AGV with Trailers}

An AGV with trailer system is composed for a vehicle in the front part, the kinematics corresponds of a vehicle with a particular configuration and a trailer or towed platform (Figure 4). That system is an interesting extension of an AGV simple and can be made attaching one or more trailers, observed actually in applications, as in convoys in the lane of baggage at airports, on transport of container in ports and even in the FMS for transport of material in the industry. There are many subtle issues to model the limitations of these models, as a form of equations that is very sensitive to the precise point at which the trailer is attached and also in the choice of the construction of the body. The theoretical formalization of the problem has been widely discussed as prior by Latombe, (1991) and presented by Murray and Sastry, (1993), Bushnell, et al., (1995), Laumond, (1998), Lamiraux, (1998) and by Lavalle, (2006).
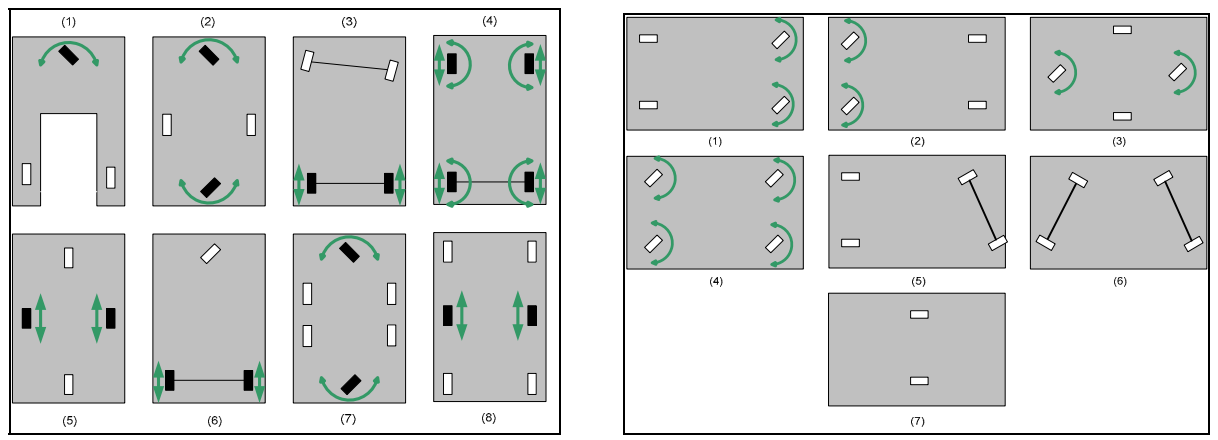

Fig. 4 Traction/direction (left) systems and common trailers (right) in systems AGV's. 
Model Example. Whereas a simple vehicle and designed according to the combination of different settings that pull $k$ trailers as shown in Figure 5, each trailer is attached to the center of the rear axle of the body in front of vehicle. The new important parameter is the length of the coupling $d_{i}$, which is the distance from the center of the rear axle of the trailer $n$ to the point where the trailer is coupled to the next body. The vehicle itself contributes to $R^{2} \times \mathbf{S}^{1}$ for $C$, and each trailer contributes to a $\mathbf{S}^{1}$ component for $C$. The dimension of $C$, is for so much $k+3$. $\theta_{i}$ denote the orientation of $i$-th trailer, expressed in relation to the frame of the world.
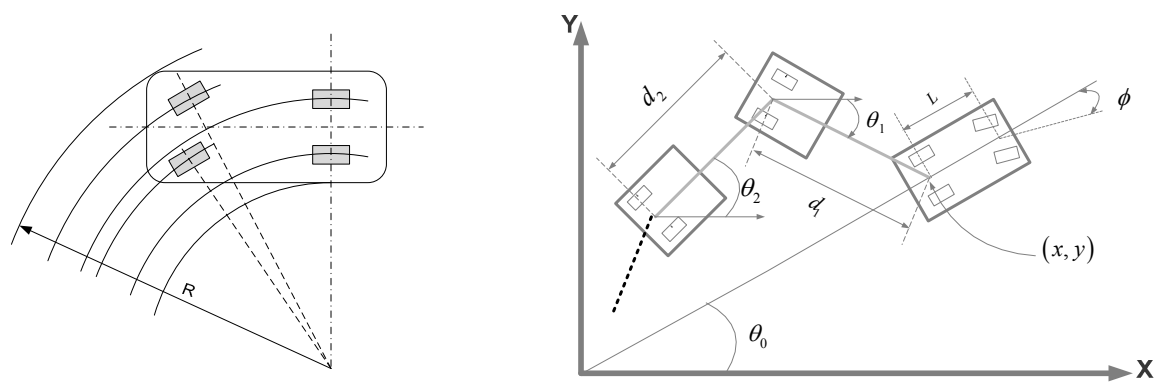

Fig. 5 Parameters for an AGV with $n$ trailers.

The configuration of the transition equations for the model of the figure 5 is given for:

$\dot{x}=s \cos \theta_{0} ; \quad \dot{y}=s \operatorname{sen} \theta_{0} ; \quad \dot{\theta}_{0}=\frac{s}{L} \tan \phi ; \quad \dot{\theta}_{1}=\frac{s}{d_{1}} \operatorname{sen}\left(\theta_{1}-\theta_{0}\right)$

In general, obtain that for the presented model, can be given for:

$$
\begin{aligned}
& \dot{\theta}_{i}=\frac{s}{d_{i}}\left(\prod_{j=1}^{i-1} \cos \left(\theta_{j-1}-\theta_{j}\right)\right) \operatorname{sen}\left(\theta_{i-1}-\theta_{i}\right) \\
& \dot{\theta}_{k}=\frac{s}{d_{k}}\left(\prod_{j=1}^{k-1} \cos \left(\theta_{j-1}-\theta_{j}\right)\right) \operatorname{sen}\left(\theta_{k-1}-\theta_{k}\right)
\end{aligned}
$$

The filtration of $k$ trailer is a problem is very complex. For smaller values of $k$, the control can be verified directly. For the general case, a calculation very detailed and organized by Laumond (1998) shows that the system is monitored with a degree of nonholonomic $k+3$ and vector of relative growth $\sigma=(2,1, \cdots, 1)$. An interesting variation of this model is to allow wheels to the trailer for an only trailer, this conduces to a model that is similar to the study realized by Bushnell, et al., (1995). A modeling of the trajectory of the system quoted is show in figure 6 and figure 7. Others model and configurations were studied, but are not exposed in the present work. 

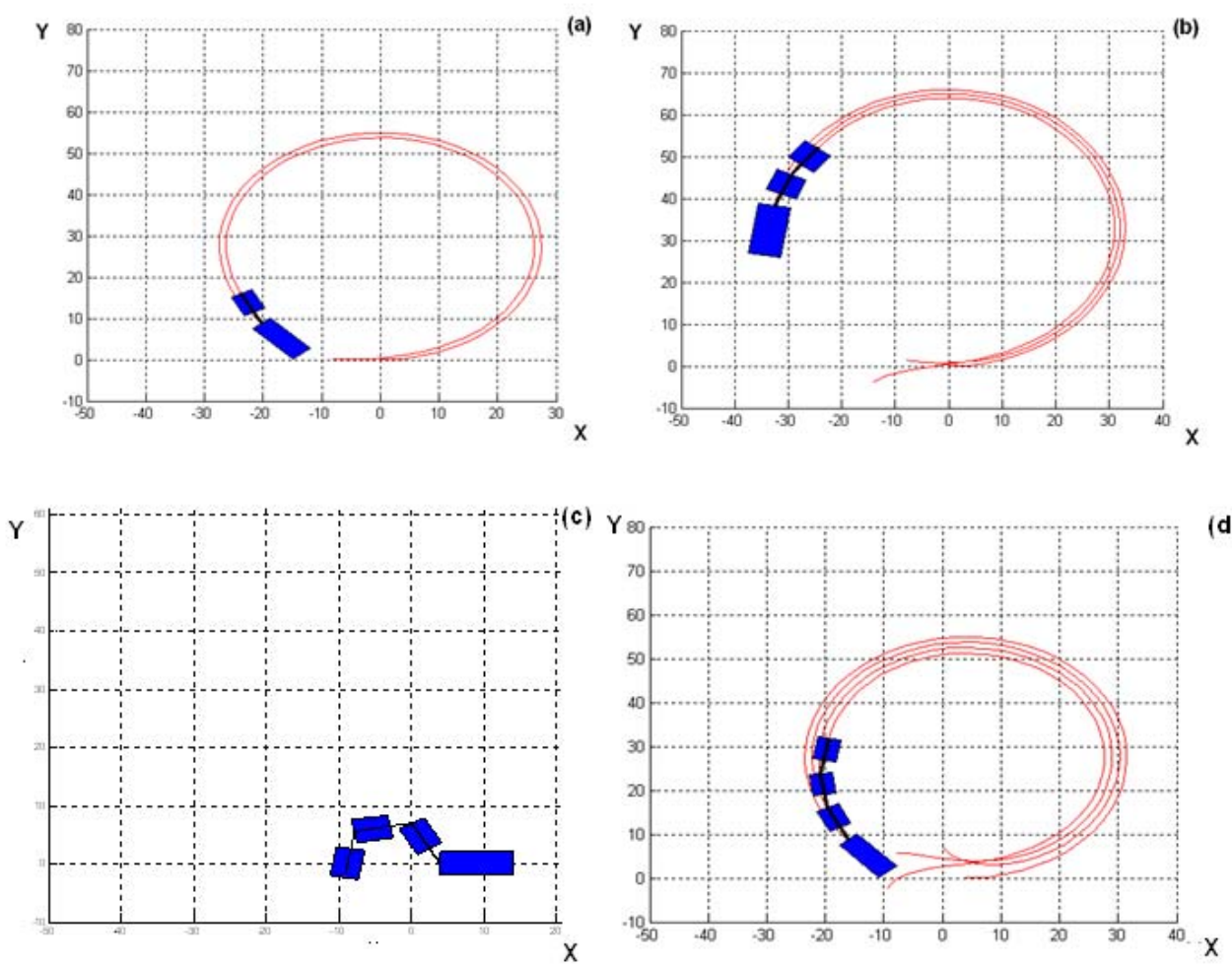

Fig. 6 Modeling preliminary of the trajectories of an AGV with three trailers for a constant angle (a) 1-trailer, (b) 2-trailer, (c) initial position 3-trailer, and (d) 3-trailer.
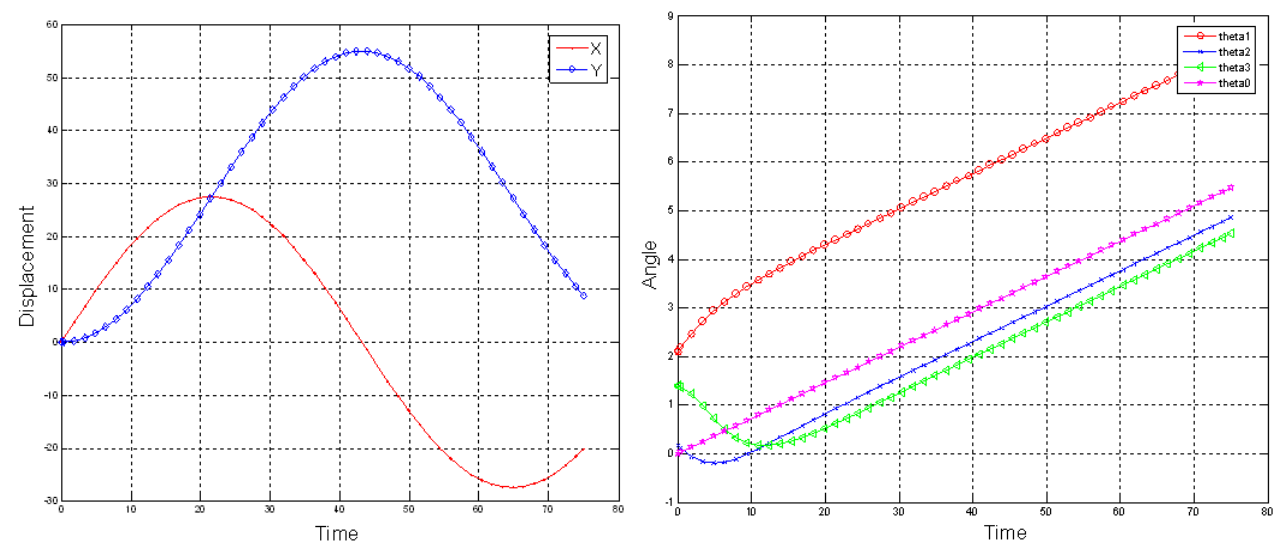

Fig. 7 (a) Displacement generated AGV on $x$ and $y$, (b) tendency of angles for 3-trailers. 


\section{Conclusions and Directions for Future Work}

The present work opens up a path to the study of AGV's with trailers in the areas of control and optimization of paths using different configurations of vehicles and trailers. This involves the identification and planning of trajectories, in order to support the development of new optimization techniques to minimize the cost function of the behavior of automated vehicles. To reduce tires wear out and to reduce energy consumption in this type of vehicle, by planning trajectories with smaller angle variations, are intentions of this introductory work (Figure 8). A distributed architecture for the control of AGV navigation based on the SER (Scheduling by Edge Reversal) (França, 1994) graph dynamics is under development as an automatic signaling mechanism of intersections, allowing the competitive traffic of AGV's throughout the available areas of a FMS.

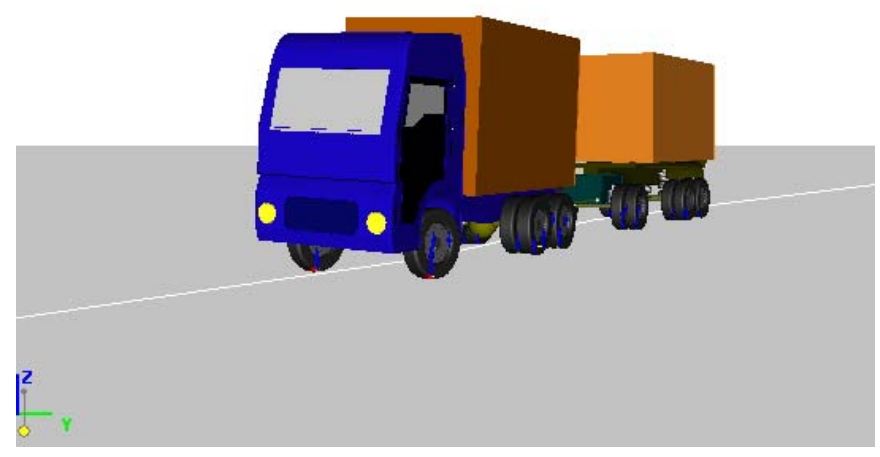

Fig. 8 AGV prototype test on trajectories - Universal Mechanism ${ }^{\circledR}$ (Winkler, 2000)

\section{References}

1. Borenstein J., Koren, Y., "Real-time obstacle avoidance for fast mobile robots", IEEE Transactions on Systems, Man and Cybernetics, Vol. 19, No. 5, pp. 1179 - 1187, 1989.

2. Bushnell, L. G., Tilbury, D. M., Sastry, S. S., "Steering three-input nonholonomic systems: the fire truck example", International Journal of Robotics Research, Vol. 14, pp. 366 - 381, 1995.

3. Chengqing, L., Ang Jr. M.H., Krishnan, H., Yong, L.S., "Virtual Obstacle Concept for Local Minimum Recovery in Potential Field Based Navigation", Proceedings of the 2000 IEEE International Conference on Robotics and Automation, Vol. 2, pp. 983-988, 2000. 
Automated Guided Vehicles (AGV): Searching a Path in the Flexible....

Pojazdy kierowane automatycznie $(A G V)$ : poszukiwanie drogi...

4. França, F.M.G., "Neural Networks as Neighborhood-Constrained Systems", $\mathrm{PhD}$. Thesis, Imperial College, London, England, 1994.

5. Khatib O., "Real-Time Obstacle Avoidance for Manipulators and Mobile Robots", In: Proceedings IEEE International Conference on Robotics and Automation, Vol. 2, pp. $500-505,1985$.

6. Lamiraux, F., Laumond, J.-P., "A Practical Approach to Feedback Control for a Mobile Robot with Trailer", In: Proc. of the IEEE Int. Conf. on Robotics \& Automation, Belgium, pp. 3291-3296, 1998.

7. Latombe, J. C., Robot Motion Planning, Kluwer Academic Publishers, 1991

8. Laumond, J.-P., Robot Motion Planning and Control, New York, SpringerVerlag, 1998.

9. Lavalle, S.M., Planning Algorithms, Cambridge University Press, 2006.

10. Le-Anh, T., De Koster, M., "A review of design and control of automated guided vehicle systems", European Journal of Operational Research, Vol. 171, No. 1, pp. $1-23,2006$.

11. Lengerke, O., Dutra, M. S., "Projetos Mecatrônicos: Na Indústria e na Academia", In: Proc. III Workshop Cooperação Universidade Empresa: Inovação Tecnológica, Taubaté, São Paulo, Brasil, 2007.

12. Lengerke, O., Trajano, A.A., Dutra, M. S., Morado, F., "Método do Campo Potencial Virtual Modificado para Geração de Caminho com Obstáculos Poligonais". In: $8^{\circ}$ Congreso Iberoamericano de Ingeniería Mecánica - CIBIM8 - Cusco-Perú, 2007.

13. Murray, R.M., Sastry, S.S., "Nonholonomic Motion Planning: Steering Using Sinusoids", IEEE Transactions on Automatic Control, Vol. 38, No. 5, pp. 700 716, 1993.

14. Reveliotis, S.A., "Conflict resolution in AGV systems". IIE Transactions Vol. 32, No. 7, Springer, pp. 647-659, 2000.

15. Winkler, C.B., "Rollover of Heavy Commercial Vehicles", UMTRI Research Review, University of Michigan Transportation Research Institute, v. 31, n. 4, 2000 . 


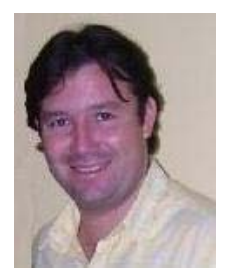

Omar Lengerke. M.Sc. in Control and Automation of Manufacture Systems, obtained in 2002 (ITESM-CEM, Mexico). Computational Systems Engineer, graduated in 1999 (UNAB, Colombia). D.Sc. student in Mechanical Engineering in Robotics since 2006 (COPPE/UFRJ, Brazil) under advising of Professor Dr.-Ing. Max Suell Dutra. More than 10 works published in national and international congresses and journals in the last 3 years. CV: http://lattes.cnpq.br/2942398586405793

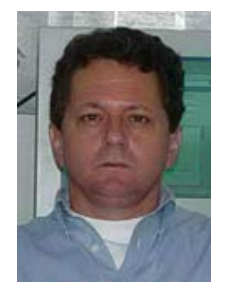

Max Suell Dutra. Dr-Ing. in Robotics, obtained in 1995 (UNIDUISBURG, Germany). M.Sc. in Mechanical Engineering in Robotics, obtained in 1990 (COPPE/UFRJ). Mechanical Engineer, graduated in 1987 (UFF, Brazil). Professor of COPPE/UFRJ, heading a research group in Automation and Robotics. Chief of the Robotics Laboratory (http://www.labrob.coppe.ufrj.br). More than 60 works published in national and international books, congresses and journals in the last 3 years. C.V.: http://lattes.cnpq.br/7801915818734316

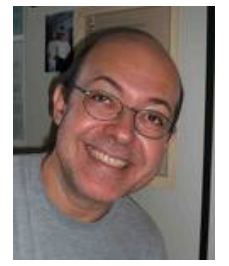

Felipe Maia Galvão França. Ph.D. in Neural System Engineering, obtained in 1994 (Imperial College of Science Technology and Medicine, IC, England). Master in System and Computational Engineering, obtained in 1987 (COPPE/UFRJ). Electronic Engineer, graduated in 1981 (UFRJ, Brazil). Associate Professor of Computer Science of COPPE/UFRJ. Experience in the area of Computer Science. Focused, mainly, in the subjects: distributed algorithms, neural networks, artificial neural networks. C.V.: http://lattes.cnpq.br/1097952760431187

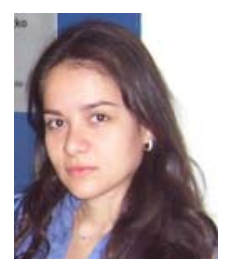

Magda Judith Morales Tavera. M.Sc. in Mechanical Engineering, obtained in 2008 (UFRJ, Brazil). Mechatronics Engineer graduated in 2005 (UNAB, Colombia). D.Sc. student in Mechanical Engineering in Robotics since 2008, under advising of Professor Dr.-Ing. Max Suell Dutra. Curriculum vitae: http://lattes.cnpq.br/1327276705657646 